\title{
Bioavailability of two oral formulas of secnidazole in healthy volunteers
}

\author{
Patrícia Andréa Bertuol Montovani*, Ana Maria Pugens Pinto, Mauricio Bedim dos Santos, \\ Daiane Loss Vieira, Anelise Weich do Prado, Josélia Larger Manfio
}

Biocinese, Centro de Estudos Biofarmacêuticos Ltda.

\begin{abstract}
Secnidazole is an antimicrobial agent used primarily in the treatment of amoebiasis. For this bioequivalence study of secnidazole, twenty-eight healthy female volunteers were enrolled in a randomized crossover study. Each volunteer was given a single oral dose of secnidazole test preparation and then the reference preparation, or vice versa, with a wash out interval of two weeks. The plasma concentrations of secnidazole were determined by HPLC, and the samples were extracted with tert-butyl-methyl-ether: dicloromethane $(60: 40, \mathrm{v} / \mathrm{v})$. Secnidazole and its parent compound metronidazole were separated on a C18 column with water:acetonitrile $(85: 15, \mathrm{v} / \mathrm{v})$ as the mobile phase, and monitored at $310 \mathrm{~nm}$. The ratio of mean $\mathrm{C}_{\max }$, $\mathrm{AUC}_{0-\mathrm{t}}$ and $\mathrm{AUC}_{0-\infty}$ values for the test and reference products were within the predetermined range established by ANVISA, demonstrating that the two formulations are bioequivalent in rate and extent of absorption.
\end{abstract}

Uniterms: Oral formulas/bioequivalence study. Secnidazole/bioavailability. Antimicrobials/ bioavailability.

Secnidazol é um agente antimicrobiano utilizado principalmente no tratamento da amebíase. Para este estudo de bioequivalência de secnidazol em voluntários saudáveis, foram incluídos vinte e oito voluntárias mulheres no estudo randomizado cruzado. Cada voluntária recebeu uma única dose oral de secnidazol do produto teste e referência para comparação, com um intervalo de wash-out de duas semanas. As concentrações plasmáticas de secnidazol foram determinados por CLAE, as amostras foram extraídas com terc-butil-metil-éter: dicloromethano (60:40, v/v). O secnidazol e seu padrão interno metronidazol foram separados em uma coluna (C18 ) com fase móvel água ultra-pura:acetonitrila (85:15, v/v) e monitorado em $310 \mathrm{~nm}$. As razões entre as médias geométricas de $\mathrm{C}_{\text {máx }}, \mathrm{ASC}_{0-\mathrm{t}}$ e $\mathrm{ASC}_{0-\infty}$, encontraramse dentro do estabelecido pela ANVISA, demonstrando que as formulações são bioequivalentes quanto à taxa e extensão de absorção

Unitermos: Formulações orais/estudo de bioequivalência. Secnidazol/biodisponibilidade. Antimicrobianos/biodisponibilidade.

\section{INTRODUCTION}

Nitroimidazoles have recently been indicated as the category of drugs offering the closest to ideal treatment for amoebiasis, due to their low toxicity (Silva, 2006). The principal derivatives of nitroimidazoles are: metronidazole, tinidazole, ornidazole, and secnidazole, (Silva, 2006; Goodman et al., 2007).

These drugs share the same common spectrum of

*Correspondence: A. M. Pugens Pinto. Biocinese - Centro de Estudos Biofarmacêuticos, Av, Ministro Cirne Lima, 1541, Vila Becker, 85903-590-Toledo - Paraná - PR, Brasil. E-mail: analitica@biocinese.com.br action against anaerobic microorganisms and are also effective in treatment of amoebiasis, giardiasis and trichomonas (Gillis et al., 1996).

Metronidazole was the first nitroimidazole for the treatment of trichomonas, a disease caused by Trychomonas vaginalis, although there are now reports that secnidazole is more effective for curing disorders caused by this pathogen (Saracoglu et al., 1998).

Secnidazole is well absorbed orally (almost 100\%) in healthy individuals, reaching a peak plasma level of 36 to $46 \mu \mathrm{g} / \mathrm{mL}$ in 1.5 to 3 hours after a single dose of $2 \mathrm{~g}$. Akin to metronidazole, secnidazole is transformed in the 
liver, principally by oxidation, as it does not induce nor inhibit iso enzymes of $\mathrm{CP}_{450}$, and its principal metabolite while inactive is RP-35843. It has a plasma half life of 17 to 29 hours in men and 14 hours in women (Klasco et al., 2006).

Studies of bioavailability and equivalence are used to determine the blood pharmaceutical concentration of the test pharmaceutical compared to the reference medication. Based on these studies, therapeutic equivalence is confirmed for the generic product, which represents a less costly alternative for the general population.

This study was designed to evaluate the bioavailability of two medications containing secnidazole $1000 \mathrm{mg}$, to determine their bioequivalence. The test product, secnidazole $1000 \mathrm{mg}$, was obtained from Prati, Donaduzzi Laboratories, while the reference was secnidazole (Secnidal ${ }^{\circledR}$ ) $1000 \mathrm{mg}$ from Adventis Pharma Laboratory.

\section{MATERIAL AND METHODS}

\section{Material}

Secnidazole $1000 \mathrm{mg}$, tablet form (test medication) Secnidal ${ }^{\circledR} 1000 \mathrm{mg}$ tablet form (reference medication) Secnidazole (Study standard - Siddharth International) Metronidazole (Internal standard-secondary standardAarti Drugs)

\section{Reagents}

Distilled water

Acetonitrile HPLC Grade (TEDIA)

Methyl-tert-butyl-ether (TEDIA)

Dichloromethane (TEDIA)

\section{Equipments}

High Performance Liquid Chromatography (HPLC) Software LC Solution-Shimadzu ${ }^{\circledR}$

Automatic pipettes EP 20, 200, 1000, and $5000 \mu \mathrm{L}$

Ultra Freezer, ILSHIN

Freezer, Electrolux FE26

Refrigerated Centrifuge, CIENTEC 5000R

Vortex Tube Agitator, AP 56 PHOENIX

Bain Marie- TECNAL

WinNolin Pharsight ${ }^{\mathbb{B}}$

\section{Volunteer Selection}

Twenty-eight healthy female volunteers between the ages of 18 and 50 years, with a body mass index of $\geq$ than
19 and $\leq 27$ and no serious diseases were selected after a medical exam. Before the study, the volunteers underwent a clinical history, clinical exam, laboratory tests and electrocardiogram.

All patients read and signed an informed consent statement before entering the study, which was approved by the Research Ethics Committee of the Hospital de Clínicas in Curitiba, Paraná.

The study involved two hospitalizations of 23 hours with a two-week interval. Volunteers were admitted to a private clinic, and were fasting for 8 hours before the study which began at 7 a.m. During the study, the volunteers received a standard diet and had vital signs (blood pressure, pulse) and temperature monitored constantly.

The pre-dose blood sample was collected in a heparinized vacutainer about 60 minutes before the medication was given. Further blood samples were collected at the following times after administration: at one hour, then every 20 minutes for the next 6 samples, then half hourly for two samples, then at 4,6,10 48 and 96 hours after administration (corresponding to the following times:1:00; $1: 20 ; 1: 40 ; 2: 00 ; 2: 40 ; 3: 00 ; 3: 30 ; 4: 00 ; 6: 00 ; 10: 00 ; 48: 00$ and 96:00 hours).

Samples were centrifuged at $3000 \mathrm{rpm}$ for $10 \mathrm{mi}-$ nutes at $4{ }^{\circ} \mathrm{C}$, and the plasma was then transferred into cryogenic tubes and stored in a freezer at $-20^{\circ} \mathrm{C}$. After freezing, the samples were transported to the analytic laboratory.

\section{Study Design}

The study was a randomized open "crossover" consisting of two time periods, using a single oral dose for each administration and a washout period between administrations. Patients were randomized to receive either the test drug followed by the reference drug or vice versa. Blood samples were collected to allow for at least three half-lives of the agent to elapse. A wash out period of two weeks was allowed to be certain of elimination of secnidazole $1000 \mathrm{mg}$, which has a half-life of about 21 hours.

\section{Bioanalytical Methods}

The bioanalytical method devised to quantify secnidazol levels in human plasma was validated by examining the following parameters, as set forth in Resolution N.899 of May 29, 2003 (Brasil, 2003): specificity, linearity, recuperation, quantification limits, detection limit, precision and accuracy, robustness, and stability.

Plasma samples containing secnidazole were analyzed using High Performance Liquid Chromatography 
(HPLC), with metronidazole as the internal standard. A total of $300 \mu \mathrm{L}$ of plasma was transferred to an Eppendorf tube and $40 \mu \mathrm{L}$ of standard solution $(1000 \mathrm{ug} / \mathrm{mL}$ dissolved in acetonitrile $20 \%$ ), was added, and the tubes then agitated in a vortex for 30 seconds.

Extraction was done using $4 \mathrm{~mL}$ of methyl-tertbutyl-ether $(60: 40, \mathrm{v} / \mathrm{v})$ and the tubes were spun for a further 90 seconds and then centrifuged at 2,700 rpm for 20 minutes at $4{ }^{\circ} \mathrm{C}$. After centrifugation, the organic phase was separated and evaporated under nitrogen at $45^{\circ} \mathrm{C}$ until dry. The residue was reconstituted with $200 \mu \mathrm{L}$ of acetonitrile $15 \%$. The mobile phase was reconstituted with distilled water: acetonitrile (85:15). Analysis was done under flux of $1.0 \mathrm{~mL} / \mathrm{min}$ and volume of injection was $50 \mu \mathrm{L}$.

The HPLC system used was Shimadzu (Kyoto, Japan) model LC-20AT with a quaternary system of bombardment and an automatic degasification module for the mobile phase. Detection was done using UV at $310 \mathrm{~nm}$. Chromatographic separation was done on a Kromasil C 18 (150x4.6 mm, $5 \mu \mathrm{m})$.

Concentration calculations of the samples were done using the software LC Solution ${ }^{\circledR}$, provided with the HPLC system. The ratio of the area of the peak of secnidazole and the internal standard metronidazole were used as the calibration curve, using a linear regression model with a weight of $1 / x$, for the straight line equation: $y=a x+b$, where $y$ corresponds to the areas of secnidazole/metronidazole and $x$ refers to the concentration of Secnidazole; $b$ is the intersection of the line with the $y$ axis and a corresponds to the slope of the line.

\section{Pharmacokinetic Analysis}

The maximum peak concentration $\left(\mathrm{C}_{\max }\right)$ and the time to attain this concentration $\left(\mathrm{T}_{\max }\right)$ were obtained directly from the details of plasma concentration versus time. The plasma half-life was found using the following equation: $T_{1 / 2}$ $=0.693 / K_{l e}$, where the elimination constant $\left(\mathrm{K}_{\mathrm{el}}\right)$ was calculated from the inclination coefficient of the regression line adjusted for at least the last three concentration values in log $\mathrm{n}$ format. The area under the curve of concentration versus time, from time zero until the final collection $\left(\mathrm{AUC}_{0-\mathrm{t}}\right)$ was obtained using the method of trapezoids. The area under the curve from zero until infinity $\left(\mathrm{AUC}_{0-\infty}\right)$ was calculated as follows: $\mathrm{AUC}_{0-\infty}=\mathrm{AUC}_{0-\mathrm{t}}+C_{\mathrm{t}} / K_{l e}$, where $\mathrm{C}_{\mathrm{t}}$ is the last measured concentration (Chow et al., 2000).

\section{Statistical Analysis}

The pharmacokinetic parameters $\mathrm{C}_{\max }, \mathrm{AUC}_{0-\mathrm{t}}$ and $\mathrm{AUC}_{0-\infty}$, were analyzed after logarythmic transformation
(In). ANOVA analysis of variance for crossover studies was used, as well as the details of Cmax, $\mathrm{AUC}_{0-\mathrm{t}}$ and $\mathrm{AUC}_{0-\infty}$, to determine the effects of the sequence and volunteer within the sequence, formulation, and time period.

A 90\% Confidence Interval (CI) was used for the ratio of the geomentric means of the transformed data for the test medication and the reference standard (test/reference). The two medications were considered bioequivalent when the $90 \% \mathrm{CI}$ of the ratio of the means was between 80 and 125\% (Brasil, 2006).

\section{RESULTS AND DISCUSSION}

Twenty eight female volunteers with a mean age of 28 years, mean weight of $59.05 \mathrm{~kg}$, mean height of $1.61 \mathrm{~m}$ and mean BMI of 22.81, participated in the study. The following inclusion criteria were observed: healthy female volunteers, not pregnant and not nursing, with a Body Mass Index $\geq 19$ and $\leq 27$, willing to sign an informed consent form, and comply with the study protocol. The laboratory exams applied were: clinical history, physical and psychological examination, blood pressure and pulse, EEG and complementary laboratory exams. Subjects also had to be able to understand the nature and objective of the study and be willing to cooperate with the Investigator and adhere to all the study requirements.

The method used in the study has some advantages compared to other methods using HPLC, as described in the literature. Ravi and coauthors (1997) used dichloromethane as an extraction solvent, which led to some difficulties in processing of the samples and in recuperation and accuracy of the results. In the present study, a strongly non-polar solvent, methyl-tert-butyl-ether $(60: 40, \mathrm{v} / \mathrm{v})$ was used for extraction, improving processing conditions and results, while providing greater ease, speed and recuperation during extraction of the samples.

In another bioanalytical method, Bibi et al. (2002) used $\mathrm{ZnSO}_{4}$ and $\mathrm{NaOH}$ in the extraction by precipitation, which yielded extracts with a greater number of impurities compared to liquid-liquid extraction. In the two studies cited above, the mobile phase consisted of acetonitrile: $0.02 \mathrm{M}$ sodium acetate $(10: 90 \mathrm{v} / \mathrm{v})$ adjusted for $\mathrm{pH}$ and a chromatography column of $250 \mathrm{~mm}$ in length. However, the present study used a mobile phase of water: acetonitrile $(87: 13 \mathrm{v} / \mathrm{v})$, which did not need $\mathrm{pH}$ adjustment and or an acetate buffer, which leads to marked wear in the chromatographic column and compartments of the HPLC. Therefore, the method which we used is easier, more practical, precise and cost effective. The run time in this study was 6 minutes, which is shorter than that used by Niadu et al. (1997) and Bibi et al. (2002). This short time was probably due to 
the column length of $150 \mathrm{~mm}$, which allowed analysis of a larger number of samples in a shorter time period, with greater economy of reagents, since bioequivalence studies usually involve an average of 1300 samples.

According to Ravi et al. (1997), in order to obtain a quantification limit in a concentration less than $1000 \mathrm{ng} / \mathrm{mL}$, an electron capture detector should be used. However, in the current study a quantification limit of $300 \mathrm{ng} / \mathrm{mL}$ was observed without the need for this detector.

The method employed in this study followed the legislation in force (Brasil, 2003) and the stability of the pharmacologic agent in plasma was also proven. The parameters of precision and accuracy yielded values of $6.37 \%$ and $100.21 \%$ for CBQ; $4.62 \%$ and $106.88 \%$ for CMQ and $4.90 \%$ and $108.95 \%$ for CQA, respectively. For linearity, the value found was 0.9980 , the angular coefficient was 41697.07 and the line intercept was -16.3680 . Recuperation values were $99.22 \%$ for secnidazole and $85.58 \%$ for the internal standard metronidazole. The samples remained stable during the three cycles of freezing and thawing in the short-term of 4 hours, post-processing of 48 hours, and long-term of 56 days afterward, indicating adequate stability of the plasma samples of volunteers from the time of collection to the last analysis.

Figure 1 shows the chromatographic profile of secnidazole.

The analytic method used in this study for the quantification of secnidazole in plasma samples can also be applied in bioequivalence studies.
The curve of mean plasma concentration versus time for the test medication and the reference is shown in Figure 2, demonstrating similar absorption, distribution and elimination for both drugs.

The pharmacologic parameters of the reference and test medications are shown in Table 1.

The plasma half-life $\left(\mathrm{T}_{1 / 2}\right)$ of both products was similar, with a mean of 19.60 hours. In a similar study, Bibi et al. (2002) found a plasma half life of 13.86 hours; although Tenenbaum et al. (1993), in a study which used $2 \mathrm{~g}$ of secnidazole, found a greater half-life of 28.80 hours. The time taken to reach maximum concentration $\left(\mathrm{T}_{\max }\right.$ in our study was. on average, 1.64 hours. Bibi et al (2002) found a mean $\mathrm{T}_{\text {msx }}$ of 1.77 whereas Shahid (2001) found a $\mathrm{T}_{\text {max }}$ of 5.03 hours in male volunteers. The maximum mean concentration found in the present study was $24,899.32 \mathrm{ng} / \mathrm{mL}$, above the value of $16,240.00 \mathrm{ng} / \mathrm{mL}$ found by Bibi et al. (2002). Ravi et al. (1997) however, found a $C_{\max }$ of $25,680.00 \mathrm{ng} / \mathrm{mL}$ in six male volunteers.

The ANOVA results for the parameters Cmax, $\mathrm{AUC}_{0-96}$ and $\mathrm{AUC}_{0-\infty}$ shown in Table II demonstrate no significant difference in the formulations, period and sequence at a level of significance of $\alpha=0.05$, indicating equivalence of the bioavailability means of secnidal ${ }^{\circledR}$ and Secnidazole.

The difference found in effect of volunteer (sequence) for the parameters $\mathrm{C}_{\text {max }}, \mathrm{AUC}_{0-96}$ and $\mathrm{AUC}_{0-\infty}$, reflects individual variability. The ratio of the geometric means for $\mathrm{C}_{\max }$, was $99.46 \%$, with a $90 \% \mathrm{CI}$ (Confidence

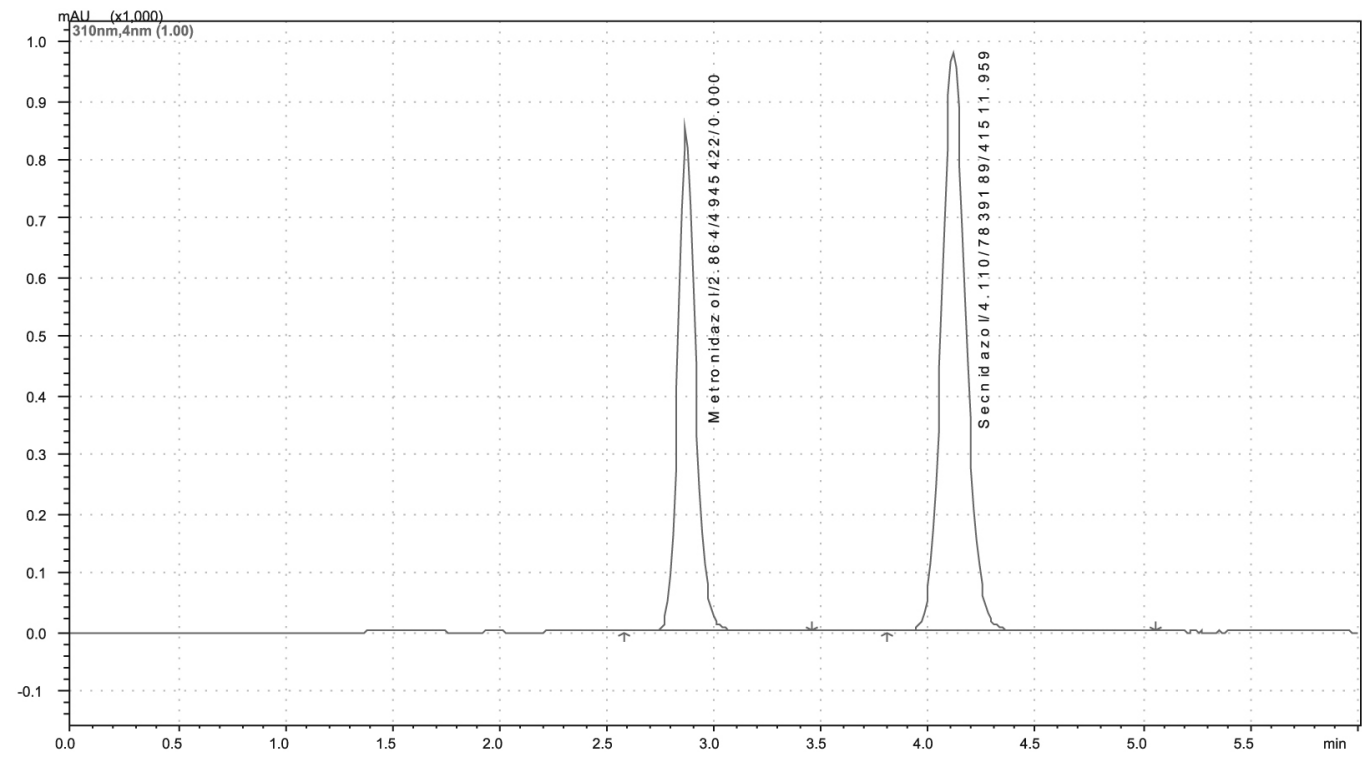

FIGURE 1 - Chromatograph obtained from volunteers after administration of $1000 \mathrm{mg}$ of secnidazole added to the internal standard, with retention times of 2.8 and 4.1 minutes, respectively. Chromatographic conditions: column C 18-Kromasil Akzo-Nobel, 150 mm $\mathrm{x} 4.6 \mathrm{~mm}$; mobile phase consisted of distilled water and acetonitrile $(85: 15 \mathrm{v} / \mathrm{v})$ with elution rate of $1 \mathrm{~mL} / \mathrm{min}$ at a temperature of $40{ }^{\circ} \mathrm{C}$ and UV detection of $310 \mathrm{~nm}$. 


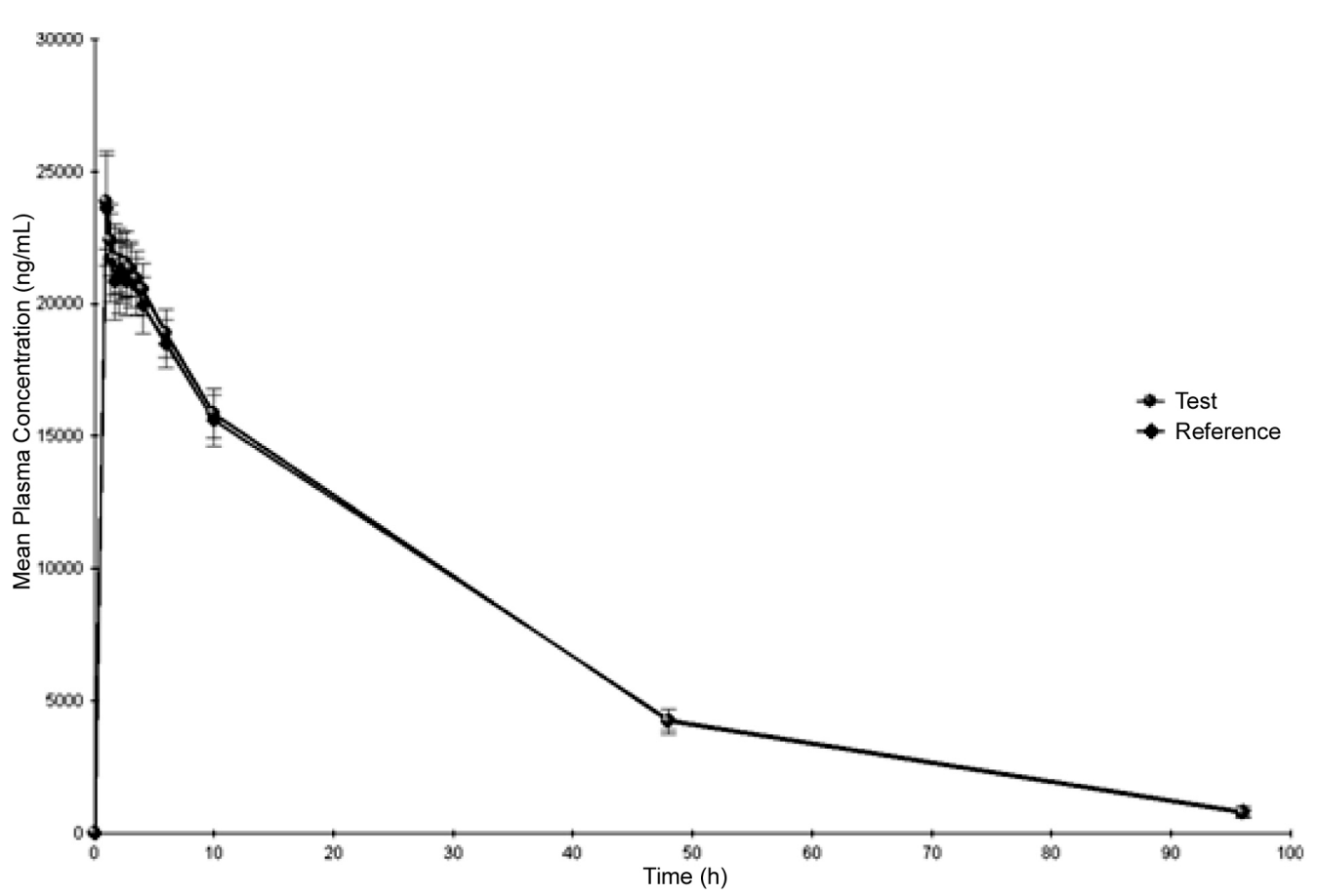

FIGURE 2 - Profile of mean plasma concentrations ( \pm 2 standard errors) of secnidazole versus time, for one dose of the test and reference formulations of an oral dose of secnidazole $1000 \mathrm{mg}$.

TABLE 1 - Pharmacologic parameters of the reference standard and test medications

\begin{tabular}{lcc}
\hline Pharmacokinetic Parameter & Secnidal $^{\circledR}$ & Secnidazole \\
\hline $\mathrm{T}_{\text {max }}(\mathrm{h})$ & 1.83 & 1.45 \\
Mean (Standard Deviation) & $(2.00)$ & $(1.08)$ \\
$\mathbf{C}_{\text {max }}$ (ng/mL) & $25,020.35$ & $24,778.29$ \\
Mean (Standard Deviation) & $(4101.64)$ & $(3329.89)$ \\
$\mathbf{K}_{\text {el }}(\mathbf{1} / \mathbf{h})$ & 0.04 & 0.04 \\
Mean (Standard Deviation) & $(0.01)$ & $(0.01)$ \\
$\mathbf{T}_{1 / 2}(\mathbf{h})$ & 19.97 & 19.23 \\
Mean (Standard Deviation) & $(4.29)$ & $(3.35)$ \\
AUC $_{\mathbf{0 - 9 6}}$ (ng/mL.h) & $676,436.39$ & $684,080.84$ \\
Mean $($ Standard Deviation) & $(103,797.75)$ & $(11,866.61)$ \\
AUC $_{\mathbf{0 - \infty}}$ (ng/mL.h) & $707,181.13$ & $707,925.29$ \\
Mean (Standard Deviation) & $(105,924.32)$ & $(124,391.66)$ \\
\hline
\end{tabular}

$\mathrm{T}_{\max }=$ Time to reach maximum concentration; $\mathrm{C}_{\text {máx }}=$ Maximum concentration obtained; $\mathrm{K}_{\mathrm{el}}=$ Elimination constant; $\mathrm{T}_{1 / 2}=$ Plasma elimination half-life; $\mathrm{AUC}_{0-96}=$ Area under the concentration curve versus time from $0-96$ hours; $\mathrm{AUC}_{0-\infty}=$ Area under the concentration curve versus time extrapolated to infinity

Interval) of $95.97 \%-103.07 \%$. For $\mathrm{AUC}_{0-96}$ the ratio of geometric means was $100.88 \%$ with a $90 \%$ CI of $97.98 \%$ $-103.86 \%$; and for $\mathrm{AUC}_{0-\infty}$, the ratio was $99.71 \%$ with a $90 \%$ CI of $96.59 \%-103.60 \%$.
TABLE II - Analysis of Variance (ANOVA) of the Pharmacokinetic Parameters

\begin{tabular}{lccc}
\hline Parameter & Treatment & Statistic F & P-Value \\
\hline $\mathbf{C}_{\max }$ & Sequence & 2.1677 & 0.1529 \\
& $\begin{array}{c}\text { Volunteer } \\
\text { (Sequence) }\end{array}$ & 6.3184 & $0.0000^{*}$ \\
& $\begin{array}{c}\text { Formulation } \\
\text { Period }\end{array}$ & 0.0668 & 0.7980 \\
& 0.1296 & 0.7217 \\
\hline $\mathbf{A U C}_{\mathbf{0 - 9 6}}$ & Sequence & 0.1849 & 0.6708 \\
& $\begin{array}{l}\text { Volunteer } \\
\text { (Sequence) }\end{array}$ & 12.2485 & $0.0000^{*}$ \\
& Formulation & 0.2634 & 0.6122 \\
& Period & 0.6500 & 0.4274 \\
\hline AUC $_{\mathbf{0 - \infty}}$ & Sequence & 0.2423 & 0.6267 \\
& Volunteer & 9.7477 & $0.0000^{*}$ \\
& (Sequence) & 0.0238 & 0.8785 \\
& Formulation & 0.028 \\
& Period & 0.5191 & 0.4777 \\
\hline
\end{tabular}

$\mathrm{C}_{\max }=$ Maximum Concentration; $\mathrm{ASC}_{0-96}=$ Area under the concentration curve versus time 0 to 96 hours; $\mathrm{ASC}_{0-\infty}=$ Area under the concentration curve versus time extrapolated to infinity; * significant difference $(\mathrm{p} \leq 0.05)$ 
The results of the analysis of variance with the Confidence Intervals for the above parameters prove the bioequivalence of the formulations, as the $90 \%$ CI of the ratio of means was between $80-125 \%$ (Brasil, 2006).

The power of the test used in this study was above $99.99 \%$, indicating that the number of volunteers in the study was sufficient to ensure reliability of the results.

\section{CONCLUSION}

The results of this study show that the two formulations of Senidazole (test/reference) are interchangeable, as the $90 \%$ CI of the pharmacokinetic parameters evaluated were within the range established by the regulatory agency-ANVISA.

\section{ACKNOWLEDGEMENTS}

Study funding was provided by Indústria Farmacêutica Prati, Donaduzzi \& Cia LTDA-Toledo-PR.

\section{REFERENCES}

BIBI, R. N. S.; SHAHID, M.; KIANI, S. Q. Analysis of blood for Secnidazole in female volunteers by HPLC method. J. Biol. Sci., v.2, n.11, p.769-770, 2002.

BRASIL. Leis, decretos, etc. Resolução n.899, de 29 de maio de 2003. A Agência Nacional de Vigilância Sanitária aprova o Guia para validação de métodos analíticos e bioanalíticos. Diário Oficial da União, Brasília, 2 jun. 2003. Seção 1, p. 56-59.

BRASIL. Leis, decretos, etc. Resolução n.1170, de 19 de abril de 2006. A Agência Nacional de Vigilância Sanitária Guia para provas de biodisponibilidade relativa/bioequivalência de medicamentos. Diário Oficial da União, Brasília, 24 abr. 2006. Seção 1, p. 35-55.

CHOW, S.; PEI LIU, J. Design and analysys of bioavailability and bioequivalence studies. New York: Marcel Dekker, 2002. p.8-10.
GILLIS, J. C.; WISEMAN, L. R. Secnidazole: a review of its antimicrobial activity, pharmacokinetic properties and therapeutic use in the management of protozoal infections and bacterial vaginosis. Drugs, v.51, n.4, p.621-638, 1996.

GOODMAN, A. G.; GILMAN, A. As bases farmacológicas da terapêtica. 11.ed. Rio de Janeiro: MacGraw-Hill, 2007. p.983-997.

KLASCO, R. K. (Ed.). DRUGDEX ${ }^{\circledR}$ System. Thomson MICROMEDEX, Greenwood Village, Colorado, USA. 2007. Avaiable at: <http://www.periodicos.capes.gov.br>. Accessed on: 04 jul. 2007.

SARACOGLU, F.; GOL, K.; SAHIN, I.; TURKKANI, B.; ATALAY, C.; OZTOPÇU, C. Treatment of bacterial vaginosis with oral or vaginal ornidazole, secnidazole and metronidazole. Int. J. Gynecol. Obst., v.62, p.59-61, 1998.

SHAHID, M. Biokinetics of secnidazole in male volunteers determined by HPLC method. M. Phil Pakistan. Faisalabad, 2001. [Thesis. Department of Chemistry. University of Agriculture.].

SILVA, P. Farmacologia. 7.ed. Rio de Janeiro: Guanabara Koogan, 2006. p.1094-1095.

RAVI, S. K.; RAVI, M. U. R.; SEKHAR, E. C.; RAO, T. R. K.; SHOBHA, J. C.; RANI, P. U.; SURYA, K. J. Rapid and selective analysis of secnidazole in human plasma using high-performance liquid chromatography with ultraviolet detection. J. Chromatogr. B., v.691, p.208-211, 1997.

TENENBAUM, H.; CUISINIER, F. J.; LE LIBOUX, A.; PICHARD, E.; MONTAY, G.; FRYDMAN, A. Secnidazole concentration in plasma and crevicular fluid after a single oral dose. J. Clin. Period., v.20, n. 7, p.505-508, 1993.

Received for publication on $22^{\text {th }}$ August 2007. Accepted for publication on $02^{\text {th }}$ September 2009. 